\title{
Ir-Catalyzed Cross-Coupling of Styrene Derivatives with Allylic Carbonates
}

Key words

styrenes

allylic carbonates

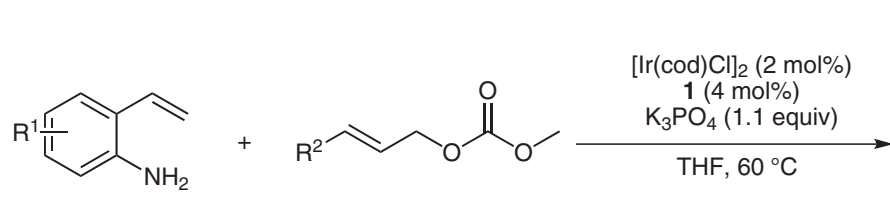<smiles></smiles>

2<smiles></smiles>

3

$1(S, S, S a), \mathrm{R}=\mathrm{Ph}$<smiles>CC(C)(C)OC(=O)c1ccccc1N</smiles>

$95 \%$ yield $2 / 3=97: 3$<smiles>CCC=CCC=Cc1ccc(C)cc1N</smiles>

$83 \%$ yield $2 / 3=99: 1$<smiles>Nc1ccccc1/C=C\C/C=C/c1ccco1</smiles><smiles>C/C=C\C/C=C\c1ccccc1N</smiles><smiles>CCC=CCC=Cc1cc(Cl)ccc1N</smiles><smiles>C/C(=C/C/C=C/c1ccc(Br)cc1)c1ccccc1N</smiles><smiles>Nc1ccccc1/C=C\C/C=C/c1cccc2ccccc12</smiles>

Significance: The iridium-catalyzed cross-coupling of o-amino-styrene derivatives with allylic carbonates is described. The procedure affords skipped Z,E-dienes with the exclusive formation of a cis double bond.
Comment: This protocol has a broad substrate scope and affords the desired products in good yield. It is noteworthy that less of the isomerized byproducts were observed in reactions involving aliphatic allylic carbonates. The proposed mechanism involves an iridium-catalyzed amine-assisted vinyl $\mathrm{C}-\mathrm{H}$ bond activation process, a notion that is supported by deuterium labeling experiments. 